\title{
MAPS AND ILLUSTRATIONS
}

\section{Maps}

1. The world war in early 1916.

2. The Ottoman Empire at the time of the First World War.

3. Sinai, Palestine and Syria.

xviii

4. The Sinai Desert. $\quad x x i$

5. The Hijaz in $1916 . \quad$ xxii

6. The zone of operations on the Arab front, May 1917-August 1918. xxiii

7. Palestine, showing major British military advances, xxiv November 1917-September 1918.

8. North-west Sinai, showing the locations of the Battles of Katia, Romani and Bir al-Abd in 1916.

9. The First Battle of Katia, 23 April 1916.

10. The Battle of Romani, 4 August 1916.

11. The Battle of Magdhaba, 23 December 1916.

12. The Battle of Rafa, 9 January 1917.

13. The First Battle of Gaza, 26-27 March 1917.

14. The Second Battle of Gaza, 19-20 April 1917.

15. The Hallat Ammar Ambush, 19 September 1917.

16. The Third Battle of Gaza, 29 October-7 November 1917.

17. The Yeomanry action at Huj, 8 November 1917.

18. The Battle of El-Mughar, 13 November 1917.

19. The area of operations around Jerusalem, 18 November- 357 9 December 1917.

20. The Battle of Tafila, 25 January 1918.

21. The Amman raid, 21 March-2 April 1918.

22. The Battle of Maan, 13-17 April 1918. 
23. The Salt raid, 30 April-4 May 1918.

24. The Battle of Mudawwara, 8 August 1918.

25. The Battle of Megiddo, 19-25 September 1918.

26. The race from Damascus to Aleppo, October 1918.

\section{Illustration credits}

Plate 1 is photographed by Harry Chase, 1917, (c) 2005 TopFoto. From T.E. Lawrence's Seven Pillars of Wisdom, subscribers' edition, 1926, the following images (artists' names follow in parentheses): plate 5 left (W. Nicholson), right (Augustus John) and bottom (William Roberts); plate 6 bottom right (Eric Kennington); and all three images on plate 7 (Eric Kennington). Plate 6 top of the Emir Feisal is by Augustus John, 1919 @ Ashmolean Museum, University of Oxford (WA1936.30). Plate 8 right of Sir Henry McMahon is by Walter Stoneman, 1920 @ National Portrait Gallery, London. Plate 11 top and plate 17 top are courtesy of the Imperial War Museum (Q58863 and Q59193). Plate 13 top is courtesy of the Huntingdon Library, San Marino, California. Plate 13 bottom is a photograph from Lt George Pascoe's album, courtesy of John B. Winterburn. Plate 20 bottom left is by Eric Kennington at Clouds Hill, Dorset (C) National Trust/R. Goldsmith. 